\title{
SPARE PARTS CRITICALITY ANALYSIS USING A FUZZY AHP APPROACH
}

\section{Orlando Durán}

Original scientific paper A distinctive characteristic of the spare parts inventory system is the need to evaluate or define the criticality of items in the inventory. Therefore, there is a need to consider factors such as cost, failure rate and availability, among others. There are few papers in literature that discuss relevant methods to define a reliable hierarchy of a set of spare parts. Up to now, no article has considered ambiguity and uncertainty factors when performing criticality analysis of spare parts. In addition, criticality analysis involves the simultaneous consideration of multiple criteria, including tangible and intangible factors; prioritizing these factors can be a great challenge and a complex task. Therefore, no attempt has been made to incorporate fuzziness into multicriteria decision-making in the criticality analysis in spare parts management. This work proposes a fuzzy-based methodology for prioritization of spare parts. The proposal is based on a multicriteria decision method called Analytical Hierarchy Process (AHP) with triangular numbers. An example is given to illustrate the proposed methodology.

Keywords: Analytic Hierarchy Process (AHP); criticality; fuzzy AHP; spare parts

\section{Analiza kritičnosti rezervnih dijelova primjenom pristupa neizrazitog analitičkog hijerarhijskog proces}

Izvorni znanstveni članak

Specifično obilježje sustava zalihe rezervnih dijelova je potreba da se procijeni ili odredi kritičnost stavki u zalihi. Stoga je, između ostalih, potrebno razmotriri čimbenike poput cijene, intenziteta kvarenja i raspoloživosti. Postoji mali broj radova u literaturi koji obrađuju relevantne metode za određivanje pouzdane hijerarhije u skupini rezervnih dijelova. Do sada, nijedan rad nije obradio čimbenike nesigurnosti i dvosmislenosti prilikom analize kritičnosti rezervnih dijelova. Uz to, analiza kritičnosti uključuje istovremeno razmatranje višestrukih kriterija, uključujući stvarne i nestvarne čimbenike; davanje prednosti tim čimbenicima može predstavljati veliki izazov i složen zadatak. Zbog toga se nije pokušalo uključiti neizrazitost (fuzziness) pri donošenju odluka o višestrukim kriterijima u analizi kritičnosti kod upravljanja rezervnim dijelovima. U ovom se radu predlaže fuzzy-temeljena metodologija kod određivanja prednosti (prioritizacije) rezervnih dijelova. Prijedlog se zasniva na metodi donošenja odluke na temelju višestrukih kriterija nazvanoj Analitički Hijerarhijski Proces (AHP) s trokutastim (triangular) brojevima. Daje se primjer za ilustraciju ove metodologije.

Ključne riječi: analitički hijerarhijski proces; kritičnost; neizraziti AHP; rezervni dijelovi

\section{Introduction}

The search for higher availability and the reduction in inventories have clearly put more pressure on the maintenance and logistics systems. Any interruption to production processes becomes costly and critical. This makes the maintenance function relevant to operations management to keep organizations productive and profitable along time. One crucial factor in maintenance operations is the correct spare parts management. A systematic approach to spare parts management can lead to minimizing inventory and machine downtime. A distinctive characteristic of the spare parts inventory system is the need to evaluate or define the criticality of items in the inventory. Therefore, there is the need to consider factors such as cost, failure rate and availability, among others. There are few papers in literature that discuss relevant methods to define a reliable hierarchy of a set of spare parts. Simple and straightforward procedures such as $\mathrm{ABC}$-Pareto analysis are frequent in industry; Bošnjaković proposed to use classical ABC analysis for the classification of spares in similarity groups [17]. However, despite the fact that the classical ABC-method is easy to understand and implement, it is only successful when the classification considers one single criterion. Teunter et al. [23] have shown that the $\mathrm{ABC}$ ranking criteria as cost value and demand volume can lead to inefficient solutions. This has led researchers and practitioners to extend the traditional $\mathrm{ABC}$ classification to a multi-criteria $\mathrm{ABC}$-analysis including other parameters like unit cost, fail rate and lead time. Bacchettiet et al. [2] investigated the gap between research and practice in spare parts management, some research initiatives were proposed to bridge the gap, namely: to generate and to integrate approaches to spare parts management; to define contingency - based managerial guidelines, to promote the accumulation of knowledge and to supplement theoretical models with practical relevance.

Prioritization and criticality analysis of spare parts is a very difficult and complex task. The following three factors can be identified as the main causes of this complexity:

(1) The tremendous number of spare parts available in inventory.

(2) The existence of incompatibilities between criteria to perform the classification.

(3) The different points of view among the different technicians that are performing the analysis.

Some methodologies and frameworks for spare parts criticality evaluation have been developed. Gajpal [11] used AHP to perform criticality analysis. The model was used to obtain comparable metrics of criticality and to classify the items into three categories, i.e.; Vital, Essential or Desiderable. Braglia et al. [5] proposed a spare parts classification scheme which uses a set of multiple attributes. In virtue of the large number of the potential operational characteristics to be considered, they established a decision diagram integrated with the analytic hierarchy process. An inventory policy matrix was defined to link the different classes of spare parts with the possible inventory management policies so as to identify the "best" control strategy for the spare stocks.

More recently, Molenaers et al. [18] presented a case study where the classification was based on two 
perspectives: process criticality and control criticality. Defining priority or criticality among spare parts involves the simultaneous consideration of multiple criteria, including tangible and intangible factors; prioritizing these factors can be a great challenge and a complex task. Bacchetti et al. [3] summarized the academic literature concerned with classification related issues for spare parts management. No article up to now, except to Kabir [12] has considered ambiguity and uncertainty factors when defining inventory items criticality. It is worth noting that the aforementioned work focuses on inventory items without focusing on spare parts. On the other hand, fuzzy logic has the capacity to handle qualitative and unquantifiable criteria showing excellent results in decision making processes.

Therefore, the main motivation of this research work is to define a spare parts criticality analysis facing the strategic and operational requirements of the organization using a multicriteria decision method incorporating concepts of uncertainty and uncompleted information. In other words, this study proposes a comprehensive spare parts criticality methodology in which the objective hierarchy is constructed and the appropriate attributes are specified using fuzzy numbers to provide guidance for criticality evaluation. The analytic hierarchy process (AHP) method [21] and fuzzy numbers are applied for dealing with the ambiguities involved in the assessment and relative importance weightings of attributes.

\section{Multicriteria decision model}

The analytic hierarchy process (AHP) developed by Saaty [21] is a decision-making tool that can handle unstructured or semi structured decisions with multiperson and multicriteria inputs. It is a decision-rule model that relaxes the measurement of related factors to subjective managerial inputs on multiple criteria. AHP has several advantages, including its acceptance of inconsistencies in managerial judgments/perceptions and its user friendliness because users may directly input judgment data without the requirement of mathematical knowledge. It also allows users to structure complex problems in the form of a hierarchy or a set of integrated levels. One of the main advantages of this method is the relative ease with which it handles multiple criteria. In addition to this, AHP is easier to understand and it can effectively handle both qualitative and quantitative data. The use of AHP does not involve cumbersome mathematics. AHP involves the principles of decomposition, pair wise comparisons, and priority vector generation and synthesis. The power of AHP has been validated by empirical application in diverse areas such as healthcare [16], planning [19, 25], mining [14], project management [1], missile systems [7], new product development [1] and manufacturing [13]. In addition AHP has been used in making decisions that involve ranking, selection, evaluation, and selection of machines and IT based systems [4, 10, 20, 22].To construct the hierarchy of objectives and attributes that allow establishing a prioritization scale an extended review of the related literature was conducted. This review focused on spare parts criticality aspects and the relationships between maintenance and logistics points of view. Therefore we distinguish two categories of attributes (or points of view) to perform the criticality analysis, including Logistics factors and Maintenance factors.

These characteristics lead the authors to propose the hierarchy used in the evaluation approach. Tab. 1 presents the detailed description of the used attributes in the fuzzy AHP model.

Table 1 Attribute structure for spare parts criticality

\begin{tabular}{|c|c|c|}
\hline Factor & Attributes & Sub attributes \\
\hline \multirow{3}{*}{ Logistics } & Replenishment & $\begin{array}{l}\text { - Lead time } \\
\text { - Ordering policy }\end{array}$ \\
\hline & Suppliers & $\begin{array}{l}\text { - Substitutability/uniqueness } \\
\text { - Proximity } \\
\text { - Responsiveness } \\
\end{array}$ \\
\hline & Economic & $\begin{array}{l}\text { - Stock out implications } \\
\text { - Stocking strategy } \\
\text { - Price }\end{array}$ \\
\hline \multirow{3}{*}{ Maintenance } & Failures & $\begin{array}{l}\text { - Frequency/rate } \\
\text { - Predictability }\end{array}$ \\
\hline & Equipment & $\begin{array}{l}\text { - Life cycle stage } \\
\text { - Criticality of the equipment } \\
\text { - Reparability }\end{array}$ \\
\hline & Operations & $\begin{array}{l}\text { - Frequency of use } \\
\text { - Maintenance policy } \\
\text { - Responsiveness } \\
\text { - Availability of technical information }\end{array}$ \\
\hline
\end{tabular}

\section{Fuzzy AHP methodology}

The Fuzzy AHP methodology extends Saaty's AHP by combining with fuzzy set theory. In the Fuzzy AHP, fuzzy ratio scales are used to indicate the relative strength of the factors in the corresponding criteria. Therefore, a fuzzy judgment matrix can be constructed. The final scores of alternatives are also represented by fuzzy numbers. The optimum alternative is obtained by ranking the fuzzy numbers using special algebra operators.

Once the attributes identification is completed, a series of spare parts have to be classified or ranked using a MCDM with the participation of domain (maintenance and logistics management) experts. For that objective, a 
fuzzy AHP approach was developed and applied to the problem of spare parts criticality analysis. The next paragraphs discuss the fuzzy-AHP methodology. The next three steps can summarize the procedure of applying Fuzzy AHP:

I Construction of a hierarchical structure for the problem to be solved

II Establish the fuzzy judgment matrix and a fuzzy weight vector.

III Rank all alternatives and select the optimal one.

Three levels compose the hierarchy of the evaluation system. The first level is the goal of the problem, that is, to define a priority list considering spare parts criticality characteristics. The two main decision criteria are placed in the second level. They are logistics and maintenance related factors. In the third level are the most relevant sub-criteria for each one of the criteria listed in level 2.

In this methodology, triangular fuzzy numbers represent all elements in the judgment matrix and weight vectors. Using fuzzy numbers to indicate the relative contribution or impact of each alternative on a criterion, a fuzzy judgment vector is then obtained for each criterion. The fuzzy judgment matrix A is built with all the fuzzy judgment vectors. The weight vector $\boldsymbol{W}$ is used to represent the decision maker's opinion of the relative importance of each criterion during the decision process.

Though the purpose of AHP is to capture the expert's knowledge, the conventional AHP still cannot reflect the human thinking style. In spite of its popularity, this method is often criticized because of a series of pitfalls associated with the AHP technique. They can be summarized as follows:

- Its inability to adequately handle the inherent uncertainty and imprecision associated with the mapping of the decision-maker's perception to exact numbers [8].

- In the traditional formulation of the AHP, human's judgments are represented as exact (or crisp, according to the fuzzy logic terminology) numbers. However, in many practical cases the human preference model is uncertain and decision-makers might be reluctant or unable to assign exact numerical values to the comparison judgments.

- Although the use of the discrete scale of 1 to 9 has the advantage of simplicity, the AHP does not take into account the uncertainty associated with the mapping of one's judgment to a number.

In order to overcome the aforementioned shortcomings, a fuzzy extension of AHP was developed to solve the hierarchical fuzzy problems.

In the next sections a fuzzy AHP technique is proposed, and an example for the evaluation and justification of advanced manufacturing system is presented

A fuzzy number $\tilde{x}$ expresses the meaning 'about $x$ '. Each membership function is defined by three parameters of the symmetric triangular fuzzy number, $(l, m, r)$, the left point, middle point and right point of the range over which the function is defined. Fuzzy membership function and the definition of a fuzzy number are shown in Fig. 1. $\mu(x)=\left\{\begin{array}{cc}1 & x=m \\ \frac{x-l}{m-l} & l \leq x \leq m \\ \frac{n-x}{n-m} & m \leq x \leq n \\ 0 & \text { otherwise }\end{array}\right.$

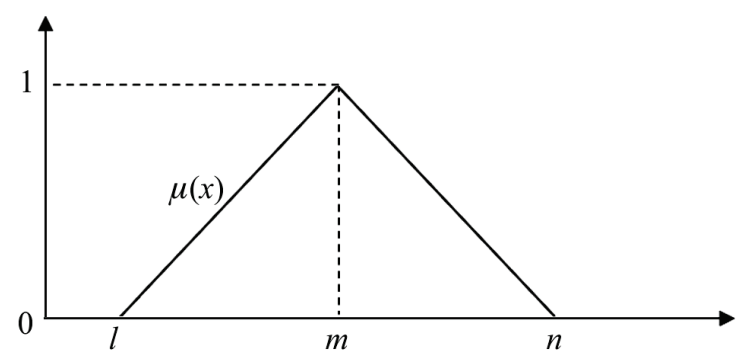

Figure 1 Membership function of a triangular number

When the decision-maker faces a complex and uncertain problem and expresses his/her comparison judgments as uncertain ratios, such as 'about two times more important', 'between two and four times less important', etc. the standard AHP steps, and specially, eigenvalue prioritization approach, cannot be considered as straightforward procedures. Indeed, the assessment of local priorities, based on pair wise comparisons needs some prioritization method to be applied. Next a brief description about addition, multiplication and division of triangular numbers is given. The fuzzy operators were adapted from [8] and are based on the extent analysis with the use of triangular fuzzy numbers for pairwise comparison scale [6].

Let $A$ and $B$ be two triangular fuzzy numbers, with their parameters as follows:

$$
\widetilde{A}=\left(a_{1}, a_{2}, a_{3}\right) \text { and } \widetilde{B}=\left(b_{1}, b_{2}, b_{3}\right) .
$$

Then, fuzzy numbers multiplication is defined by:

$\widetilde{A} * \widetilde{B}=\left(a_{1} * b_{1}, a_{2} * b_{2}, a_{3} * b_{3}\right)$

At the other hand, fuzzy numbers division is defined as follows:

$$
\widetilde{A} / \widetilde{B}=\left(a_{1} / b_{3}, a_{2} / b_{2}, a_{3} / b_{1}\right)
$$

Whilst the reciprocal value of a triangular fuzzy number $(a, b, c)$ is given by $(1 / a, 1 / b, 1 / c)$, the power of a triangular fuzzy number is given by

$\widetilde{A}^{n}=\left(a_{1}, a_{2}, a_{3}\right)^{n}=\left(a_{1}^{n}, a_{2}^{n}, a_{3}^{n}\right)$.

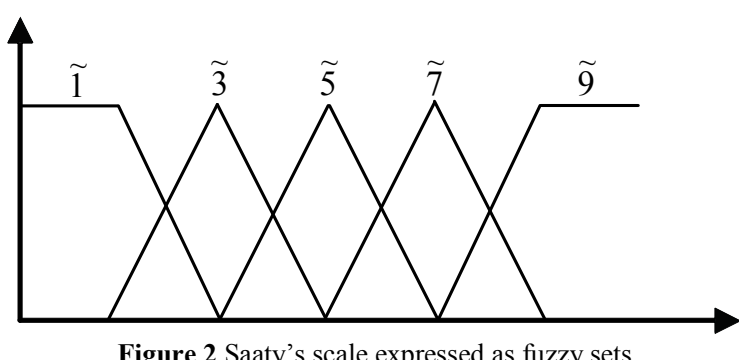

Figure 2 Saaty's scale expressed as fuzzy sets 
As can be seen in Fig. 2, the relative importance of a number over other fuzzy number is gradual and not abrupt.

Let $\widetilde{w}_{i}$ be a set of decision maker's opinion of the relative importance of one alternative over other one. The meaning of each fuzzy number is defined in Tab. 2. Using this scale we have the comparison matrix $\widetilde{\boldsymbol{A}}$, where $a_{i j}$ elements represent the estimative of the $w_{i} / w_{j}$ relation.

Table 2 Saaty's scale expressed in fuzzy numbers

\begin{tabular}{|c|l|}
\hline $\begin{array}{c}\text { Relative } \\
\text { importance }\end{array}$ & \multicolumn{1}{|c|}{ Definition } \\
\hline$\widetilde{1}$ & Equal importance \\
\hline$\widetilde{3}$ & Weak importance \\
\hline$\widetilde{5}$ & Strong importance \\
\hline$\widetilde{7}$ & Demonstrated importance over the other \\
\hline$\widetilde{9}$ & Absolute importance \\
\hline
\end{tabular}

$\widetilde{\boldsymbol{A}}=\left[\begin{array}{cccc}\frac{\widetilde{w}_{1}}{\widetilde{w}_{1}} & \frac{\widetilde{w}_{2}}{\widetilde{w}_{1}} & \cdots & \frac{\widetilde{w}_{n}}{\widetilde{w}_{1}} \\ \frac{\widetilde{w}_{1}}{\widetilde{w}_{2}} & \frac{\widetilde{w}_{2}}{\widetilde{w}_{2}} & \cdots & \frac{\widetilde{w}_{n}}{\widetilde{w}_{2}} \\ \vdots & \vdots & \vdots & \vdots \\ \frac{\tilde{\widetilde{w}}_{1}}{\widetilde{w}_{n}} & \frac{\widetilde{w}_{2}}{\widetilde{w}_{n}} & \cdots & \frac{1}{\widetilde{w}_{n}}\end{array}\right]$.

Experts' judgments or preferences among the options using Saaty's scale are represented now by triangular numbers to express subjective pairwise comparisons or capture certain degree of vagueness (Tab. 2). We know that matrix $\mathrm{A}$ is a real and positive matrix. As well as, since $a_{i j}=1 / a_{j i}$, if $\mathrm{i}$ is not equal to $\mathrm{j}, \boldsymbol{A}$ is a reciprocal matrix. Next, the eigenvector, eigenvalue and the $I C$ index are calculated, now taking these parameters as fuzzy numbers. To estimate the fuzzy eigenvector from $\boldsymbol{A}$ matrix the next equation is used:

$V_{i}=\left(\prod_{j=1}^{n} \widetilde{a}_{i j}\right)^{\frac{1}{n}}$

Therefore, we have

$V_{1}=\left(\widetilde{a}_{11} * \widetilde{a}_{12} * \widetilde{a}_{13} * \ldots * \widetilde{a}_{1 n}\right)^{\frac{1}{n}}$

$V_{n}=\left(\widetilde{a}_{n 1} * \widetilde{a}_{n 2} * \widetilde{a}_{n 3} * \ldots * \widetilde{a}_{n n}\right)^{\frac{1}{n}}$.

Eigenvector $V$ is compound by the $n$ triangular numbers defined as:

$V=\left(V_{1}, V_{2}, \ldots V_{n}\right)$

where $V_{i}$ is a triangular number defined as $\left(V_{1}, V_{m}, V_{u}\right)$. As the traditional AHP methodology, eigenvector is to be normalized according to the next relation:
$T=\left(w_{1} / \sum w_{i} w_{2} / \sum w_{i} w_{3} / \sum w_{i} \ldots w_{n} / \sum w_{i}\right)$.

That is, by dividing each element of the preference matrix with the sum of its respective column each element of the normalized eigenvector can be obtained. Where $T$ corresponds to the normalized eigenvector. From this normalized eigenvector the priorities or importance of the attributes under analysis is extracted. In order to control the result of the method, it is necessary to calculate the consistency ratio. The deviations from consistency are expressed by the following equation:

$C I=\frac{\lambda_{\max }-n}{n-1}$

The consistency ratio $(C R)$ is used to estimate directly the consistency of pairwise comparisons. The $C R$ is computed by dividing the $C I$ by a value obtained from the table of Random Consistency Index $(R I)$ created by Saaty

$C I=\frac{C I}{R I}$

If the $C R$ is less than $10 \%$, the comparisons are acceptable, otherwise not. $R I$ represents the average index for randomly generated weights. Since $\lambda \max$ is a triangular number, it has to be defuzzified into a crisp number to compute the $C I$. We suggest here using the central value of $\lambda \max$, because of the symmetry of the triangular number, the central value corresponds to the centroid of the triangular area. As an alternative, Leung and Cao [15] propose a fuzzy consistency definition with consideration of a tolerance deviation. Essentially, the fuzzy ratios of relative importance, allowing certain tolerance deviation, are formulated as constraints on the membership values of the local priorities. The fuzzy local and global weights are determined via the extension principle.

\section{Case study}

In this section, in order to prove the applicability and validity the proposed methodology is applied to a case study. A criticality analysis of a set of spare parts of a given manufacturer was taken into consideration. Intangible aspects are the factors that were considered by the methodology.

As it is known, it may be impractical to make paired comparisons among spare parts with respect to every detailed dimension or sub attribute of the hierarchy. The difficulty arises because too many attributes lead to numerous paired comparisons in AHP and may cause an inefficient process. Therefore, a simplified model was formulated. After a set of interviews, a series of six qualitative attributes was selected to perform the analysis. The six attributes are shown in Fig. 3.

This six attributes are represented here by the six following symbols: $\mathrm{AT}_{1}, \mathrm{AT}_{2}, \mathrm{AT}_{3}, \mathrm{AT}_{4}, \mathrm{AT}_{5}$ and $\mathrm{AT}_{6}$ respectively. Once the decision makers performed the pair wise comparisons for the set of attributes $\boldsymbol{A}$ matrix is 
obtained (Tab. 3). This comparison matrix is constructed by using Saaty's scale but now with triangular numbers.

To find the relative importance or priorities of the six attributes eigenvector, eigenvalue and the $R C$ index are to be computed. Thus, the eigenvector (with triangular values) is as follows:

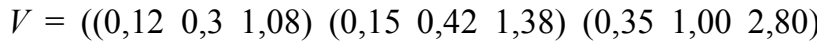
$(0,270,772,18)(0,050,120,35)(0,030,060,17))$.

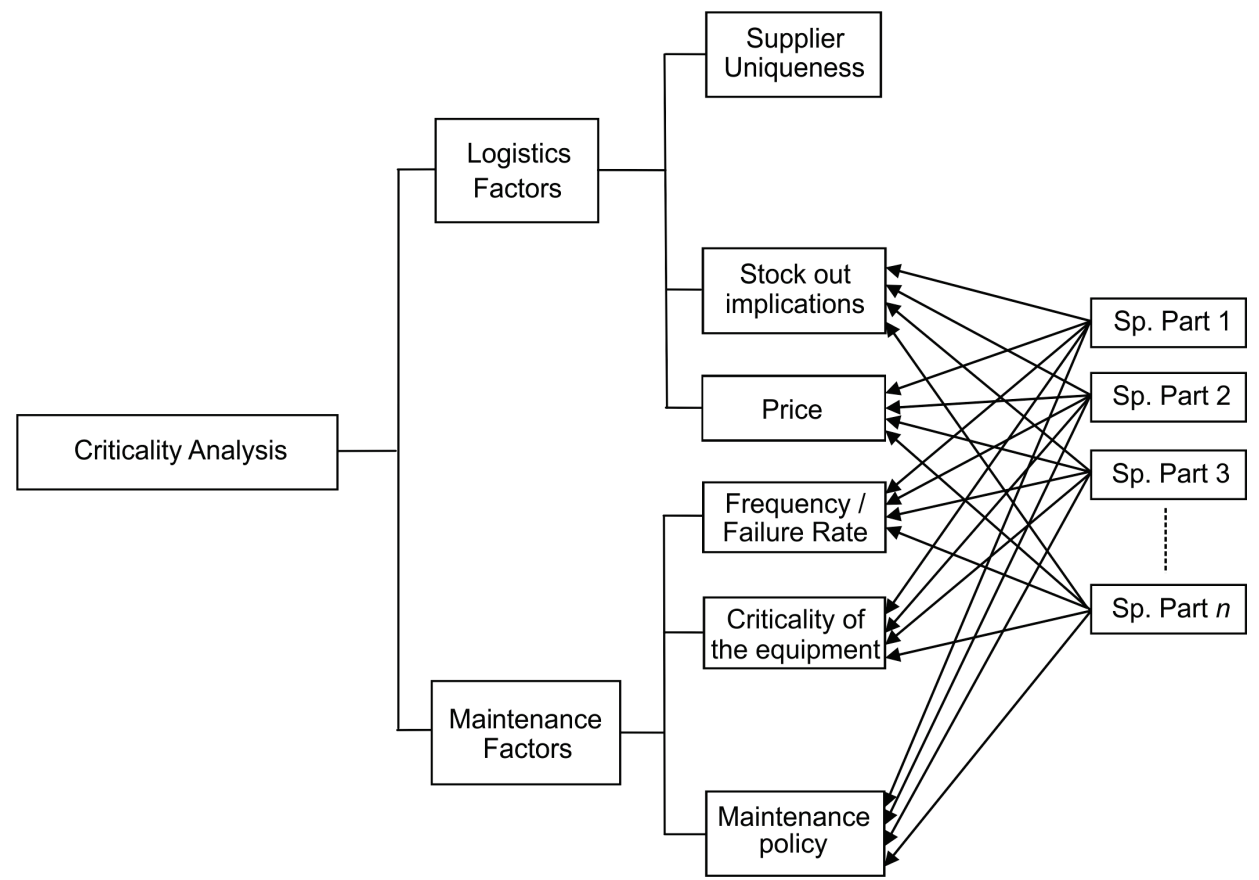

Figure 3 Hierarchy for the Spare Parts criticality analysis

Table 3 Comparisons matrix of the attributes considered for criticality analysis

\begin{tabular}{|l|c|c|c|c|c|c|}
\hline & $\mathrm{AT}_{1}$ & $\mathrm{AT}_{2}$ & $\mathrm{AT}_{3}$ & $\mathrm{AT}_{4}$ & $\mathrm{AT}_{6}$ & \\
\hline $\mathrm{AT}_{1}$ & $(1,1,3)$ & $(1 / 5,1 / 3,1)$ & $(1 / 6,1 / 4,1 / 2)$ & $(1 / 5,1 / 3,1)$ & $(1,3,5)$ \\
\hline $\mathrm{AT}_{2}$ & $(1,3,5)$ & $(1,1,3)$ & $(1 / 5,1 / 3,1)$ & $(1 / 6,1 / 4,1 / 2)$ & $(1,3,5)$ \\
\hline $\mathrm{AT}_{3}$ & $(2,4,6)$ & $(1,3,5)$ & $(1,1,3)$ & $(1 / 7,1 / 5,1 / 3)$ & $(1 / 7,1 / 5,1 / 3)$ & $(7,9,9)$ \\
\hline $\mathrm{AT}_{4}$ & $(1,3,5)$ & $(2,4,6)$ & $(3,5,7)$ & $(1,1,3)$ & $(1 / 5,1 / 3,1)$ & $(3,3,5)$ \\
\hline $\mathrm{AT}_{5}$ & $(1 / 5,1 / 3,1)$ & $(1 / 5,1 / 3,1)$ & $(3,5,7)$ & $(1,3,5)$ & $(1,1,3)$ & $(3,5,7)$ \\
\hline $\mathrm{AT}_{6}$ & $(1 / 9,1 / 7,1 / 5)$ & $(1 / 9,1 / 9,1 / 7)$ & $(1 / 5,1 / 3,1)$ & $(1 / 7,1 / 5,1 / 3)$ & $(1 / 7,1 / 5,1 / 3)$ & $(1,1,3)$ \\
\hline
\end{tabular}

Before proceeding to perform the normalizations, an additional fuzzy ranking procedure is necessary in order to compare fuzzy scores and to obtain a linear order among them. There are a number of procedures to perform the ranking process [15] and more recently, [9]; among them we propose, because of its simplicity, the utilization of the representative method, which is given by the following relation:

$\hat{A}=\frac{a_{1}+2 a_{2}+a_{3}}{4}$,

where $\boldsymbol{A}=\left(a_{1}, a_{2}, a_{3}\right)$ is a triangular number and $\hat{A}$ represents the representative ordinal of a triangular number. Considering this method and Eq. (9), the second element of the eigenvector is the highest value and corresponds to the third attribute $\left(\mathrm{AT}_{3}\right)$ operation easiness. The normalization process yields a new form of the eigenvector in which each entry is a triangular number, as follows:

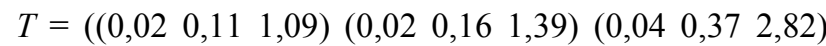
$(0,030,292,20)(0,010,050,36)(0,0040,020,17))$.
For testing the consistency of the resulting eigenvector, Saaty proposed the following relation:

$\lambda_{\max }=T * w$,

where $w$ is computed by the sum of the columns of the preferences matrix.

$w=\left(\left(\begin{array}{lll}5,3 & 11,3 & 19,5)\end{array}(4,5 \quad 8,7 \quad 15,6)(1,8 \quad 2,4 \quad 5,9)(2,6 \quad 3,9\right.\right.$ $8,9)(16,124,234,3)(25,035,045,0))$.

Next $\lambda_{\max }$ is calculated by

$\lambda_{\max }=(0,556,5598,94)$.

Then, to calculate the $C I$ (crisp) we used the central value of the triangular number $\lambda_{\text {max }}$

$C I=(6,55-6) / 5=0,11$.

In addition, $C R$ is computed

$C R=0,11 / 1,24=0,089<0,10$.

This proves total consistency of the evaluations expressed by the comparisons matrix. Based on the 
weight vector (eigenvector) the priorities or relative importance of the attributes were obtained by ranking the eigenvector values. The ranked order of the six attributes is as follows: $\mathrm{AT}_{3}, \mathrm{AT}_{4}, \mathrm{AT}_{2}, \mathrm{AT}_{1}, \mathrm{AT}_{5}$ and $\mathrm{AT}_{6}$. Next, three spare parts were compared with respect to each of the six attributes. The corresponding fuzzy pairwise comparison matrices are shown in Tab. 4.

Table 4 Fuzzy pairwise comparisons for the alternative spare parts

\begin{tabular}{|c|c|c|c|c|c|c|c|}
\hline & & $\mathrm{AT}_{1}$ & & & & $\mathrm{AT}_{2}$ & \\
\hline & Sp. Part 1 & Sp. Part 2 & Sp. Part 3 & & Sp. Part 1 & Sp. Part 2 & Sp. Part 3 \\
\hline Sp. Part 1 & $(1,01,03,0)$ & $(0,20,331,0)$ & $(0,2 \quad 0,331,0)$ & Sp. Part 1 & $(1,01,03,0)$ & $\left(\begin{array}{llll}0,33 & 1,0 & 1,0\end{array}\right)$ & $\left(\begin{array}{llll}0,33 & 1,0 & 1,0\end{array}\right)$ \\
\hline Sp. Part 2 & $(1,03,05,0)$ & $(1,01,03,0)$ & $(1,03,05,0)$ & Sp. Part 2 & $(1,01,03,0)$ & $(1,01,03,0)$ & $(0,33 \quad 1,01,0)$ \\
\hline \multirow[t]{3}{*}{ Sp. Part 3} & $(1,03,05,0)$ & $(0,20,331,0)$ & $(1,01,03,0)$ & Sp. Part 3 & $(1,01,03,0)$ & $(1,01,03,0)$ & $(1,0 \quad 1,0 \quad 3,0)$ \\
\hline & & $\mathrm{AT}_{3}$ & & & & $\mathrm{AT}_{4}$ & \\
\hline & Sp. Part 1 & Sp. Part 2 & Sp. Part 3 & & Sp. Part 1 & Sp. Part 2 & Sp. Part 3 \\
\hline Sp. Part 1 & $(1,01,03,0)$ & $(0,20,331,0)$ & $(0,110,110,14)$ & Sp. Part 1 & $(1,01,03,0)$ & $(7,09,09,0)$ & $\left(\begin{array}{llll}0,11 & 0,11 & 0,14)\end{array}\right.$ \\
\hline Sp. Part 2 & $(1,03,05,0)$ & $(1,01,03,0)$ & $(0,110,140,2)$ & Sp. Part 2 & $(0,110,110,14)$ & $(1,01,03,0)$ & $(0,140,20,33)$ \\
\hline \multirow[t]{3}{*}{ Sp. Part 3} & $(7,09,09,0)$ & $(5,07,09,0)$ & $(1,01,03,0)$ & Sp. Part 3 & $(7,09,09,0)$ & $(3,05,07,0)$ & $(1,01,03,0)$ \\
\hline & & $\mathrm{AT}_{5}$ & & & & $\mathrm{AT}_{6}$ & \\
\hline & CMMS1 & CMMS 2 & CMMS 3 & & CMMS1 & CMMS 2 & CMMS 3 \\
\hline Sp. Part 1 & $(1,01,03,0)$ & $(0,20,331,0)$ & $(0,331,01,0)$ & Sp. Part 1 & $(1,01,03,0)$ & $(4,06,08,0)$ & $(0,331,01,0)$ \\
\hline Sp. Part 2 & $(1,03,05,0)$ & $(1,01,03,0)$ & $(1,03,05,0)$ & Sp. Part 2 & $(1,03,05,0)$ & $(1,01,03,0)$ & $(0,331,01,0)$ \\
\hline Sp. Part 3 & $(1,01,03,0)$ & $(0,20,331,0)$ & $(1,01,03,0)$ & Sp. Part 3 & $(1,01,03,0)$ & $(1,01,03,0)$ & $(1,01,03,0)$ \\
\hline
\end{tabular}

Next, we can find the scores of the Spare Parts with respect to the six attributes, which are shown in Tab. 5 . The local weights of all Spare Parts for each attribute are obtained by multiplying their relative weights by the weights of the attributes. Tab. 6 shows these local weights.
Table 5 Eigenvectors of the Sp. Part with respect to the six attributes \begin{tabular}{|l|l|l}
\hline $\boldsymbol{V}_{\mathrm{AT} 1}$ & $((0,060,221,05)(0,100,461,79)(0,080,321,37))$ \\
\hline
\end{tabular} \begin{tabular}{|l|l|l}
\hline $\boldsymbol{V}_{\mathrm{AT} 2}$ & $((0,090,330,82)(0,110,330,99)(0,130,331,19))$ \\
\hline $\boldsymbol{V}_{\mathrm{AT} 3}$ & $((0,080,170,40)(0,110,250,55)(0,290,581,14))$ \\
\hline
\end{tabular} \begin{tabular}{|l|l|l}
\hline $\boldsymbol{V}_{\mathrm{AT} 3}$ & $((0,080,170,40)(0,110,250,55)(0,290,581,14))$ \\
\hline
\end{tabular} \begin{tabular}{|l|l|l}
\hline $\boldsymbol{V}_{\mathrm{AT} 4}$ & $((0,150,290,58)(0,080,160,33)(0,260,551,11))$
\end{tabular} \begin{tabular}{l|lll}
\hline $\boldsymbol{V}_{\mathrm{AT} 5}$ & $((0,070,271,03)(0,100,461,76)(0,080,271,23))$
\end{tabular} \begin{tabular}{|l|l|l}
\hline $\boldsymbol{V}_{\mathrm{AT} 6}$ & $((0,130,380,95)(0,100,340,88)(0,120,280,97))$ \\
\hline
\end{tabular}

Table 6 Local weights for the spare parts alternatives with respect to the six attributes

\begin{tabular}{|l|c|c|c|c|c|c|}
\hline & $\mathrm{AT}_{1}$ & $\mathrm{AT}_{2}$ & $\mathrm{AT}_{3}$ & $\mathrm{AT}_{4}$ & $\mathrm{AT}_{5}$ & $\mathrm{AT}_{6}$ \\
\hline Sp. Part 1 & $(0,060,221,05)$ & $(0,090,330,82)$ & $(0,080,170,40)$ & $(0,150,290,58)$ & $(0,070,271,03)$ & $(0,130,380,95)$ \\
\hline Sp. Part 2 & $(0,100,461,79)$ & $(0,110,330,99)$ & $(0,110,250,55)$ & $(0,080,160,33)$ & $(0,100,461,76)$ & $(0,100,340,88)$ \\
\hline Sp. Part 3 & $0,080,321,37$ & $(0,130,331,19)$ & $(0,290,581,14)$ & $(0,260,551,11)$ & $(0,080,271,23)$ & $(0,120,280,97)$ \\
\hline
\end{tabular}

The overall classification can be obtained by multiplying (triangular product) the weights matrix (Tab. 6) by the transposed eigenvector of the attributes (Tab. 5). Tab. 7 shows the overall classification vector.

Table 7 Overall classification vector (with triangular numbers)

\begin{tabular}{|l|l|}
\hline Sp. Part 1 & $(0,010,25$ 5,20) \\
\hline Sp. Part 2 & $(0,010,276,38)$ \\
\hline Sp. Part 3 & $(0,030,489,39)$ \\
\hline
\end{tabular}

Thus the priority scores for the Spare Parts are obtained, and they are ranked based on their magnitude (using Eq. (12)).

\section{Sp. Part $1 \quad 1,43$ \\ Sp. Part $2 \quad 1,73$ \\ Sp. Part 3 2,60}

Thus, Sp. Part 3 is considered by the users as the most critical item.

\section{Conclusions}

In this paper a Fuzzy-AHP-based methodology for defining criticality of a set of spare parts is proposed. In order to take into account the uncertainty and in order to improve imprecision in ranking attributes and/or software alternatives, the presented approach introduces triangular numbers into traditional AHP method. Adoption of fuzzy numbers allows decisions-makers to have more freedom of estimation regarding the overall importance of attributes and real alternatives. The proposed methodology was tested on a real-world example and it was found that it functions satisfactorily. We believe that this methodology is a feasible alternative to both the conventional AHP method and other Fuzzy-based approaches for spare parts criticality analysis, mainly because of its simplicity and the possibility of incorporating subjective parameters and linguistic terms in expressing main software characteristics.

\section{References}

[1] Ayag, Z. A fuzzy AHP-based simulation approach to concept evaluation in a NPD environment. // IIE Transactions. 16. (2005) pp. 827-842. DOI: 10.1080/07408170590969852

[2] Bacchetti, A.; Plebani, F.; Saccani, N. Spare parts classification and demand forecasting for stock control: Investigating the gap between research and practice. // Omega. 40, 6(2012), pp. 722-737. DOI: 10.1016/j.omega.2011.06.008

[3] Bacchetti, A.; Plebani, F.; Saccani, N.; Syntetos, A. Spare parts classification and inventory management: a case study. // Proceeding of the ISIR, $16^{\text {th }}$ Symposium on Inventories, Budapest, 2010.

[4] Bozdag, C. E.; Kahraman, C.; Ruan, D. Fuzzy group decision making for selection among computer integrated 
manufacturing systems. // Computers in Industry. 51, (2003), pp. 13-29. DOI: 10.1016/S0166-3615(03)00029-0

[5] Braglia, M.; Frosolini M.; Montanari, R. Multi-attribute classification method for spare parts inventory management. // Journal of Quality in Maintenance Engineering. $\quad 10, \quad 1(2004), \quad$ pp. 55-65. DOI: 10.1108/13552510410526875

[6] Chang, D. Y. Applications of the extent analysis method on fuzzy AHP. // European Journal of Operational Research. 95, (1996), pp. 649-655. DOI: 10.1016/0377-2217(95)00300-2

[7] Ching-Hsue, Cheng. Evaluating naval tactical missile systems by fuzzy AHP based on the grade value of membership function. // European Journal of Operational Research. 96, 2(1997), pp. 343-350. DOI: 10.1016/S03772217(96)00026-4

[8] Chiu, C.-Y.; Park, C. S. Capital Budgeting Decisions with Fuzzy Projects. // The Engineering Economist, 43, 2(1998), pp. 125-150. DOI: $10.1080 / 00137919808903193$

[9] Ciptomulyono, U. Fuzzy Goal Programming Approach for Deriving Priority Weights in the Analytical Hierarchy Process (AHP) Method. // Journal of Applied Sciences Research. 4, 2(2008), pp. 171-177.

[10] Erkan, T. E.; Can, G. F. Selecting the best warehouse data collecting system by using AHP and FAHP methods. // Tehnicki vjesnik-Technical Gazette. 21, 1(2014), pp. 8793.

[11] Gajpal, P.; Ganesh, L.; Rajendran, C. Criticality analysis of spare parts using the analytic hierarchy process. // International Journal of Production Economics. 35, (1994), pp. 293-298. DOI: 10.1016/0925-5273(94)90095-7

[12] Kabir, G.; Hasin, M. A. A. Comparative Analysis of AHP and Fuzzy AHP Models for Multicriteria Inventory Classification. // International Journal of Fuzzy Logic Systems (IJFLS). 1, 1(2011), pp. 1-16.

[13] Karsak, E. E.; Tolga, E. Fuzzy multicriteria decision making procedure for evaluating advanced manufacturing system in investments. // International Journal of Production economics. 69, (2001), pp. 49-64. DOl: 10.1016/S0925-5273(00)00081-5

[14] Kazakidis, V. N.; Mayer, Z.; Scoble, M. J. Decision making using the analytic hierarchy process in mining engineering. // Transactions of the Institution of Mining and Metallurgy Section A-Mining Technology. 113, 1(2004), pp. A30-A42. DOI: 10.1179/037178404225004274

[15] Leung, L. C.; Cao, D. On consistency and ranking of alternatives in fuzzy AHP. // European Journal of Operational Research. 124, (2000), pp. 102-113. DOl: 10.1016/S0377-2217(99)00118-6

[16] Liberatore, M. J.; Nydick, R. L. The analytic hierarchy process in medical and health care decision making: A literature review. // European Journal of Operational Research. 189, 1(2003), pp. 194-207. DOl: 10.1016/j.ejor.2007.05.001

[17] Bošnjaković, M. Multicriteria inventory model for spare parts. // Tehnicki vjesnik-Technical Gazette. 17, 4(2010), pp. 499-504.

[18] Molenaers, A.; Baets, H.; Pintelon, L.; Waeyenbergh, G. Criticality classification of spare parts: A case study. // International Journal of Production Economics. 140, 2(2012), pp. 570-578. DOI: 10.1016/j.jpe.2011.08.013

[19] Mustafa, M. A.; Albahar, J. F. Project risk assessment using the analytic hierarchy process. // IEEE Transactions on Engineering Management. 38, 1 (1991), pp. 46-52. DOI: 10.1109/17.65759

[20] Ordoobadi, S. M.; Mulvaney, N. J. Development of a justification tool for advanced manufacturing technologies: system-wide benefits value analysis. // Journal of Engineering and Technology Management. 18, 2(2001), pp. 157-184. DOI: 10.1016/S0923-4748(01)00033-9
[21] Saaty, T. L. Analytic Hierarchy Process, New York: McGraw Hill, 1980.

[22] Shamsuzzaman, M.; Sharif Ullah A. M. M.; Bohez, E. L. J. Applying linguistic criteria in FMS selection: fuzzy set AHP approach. // Integrated manufacturing. 14, 3(2003), pp. 247-254. DOI: 10.1108/09576060310463190

[23] Teunter, R. H.; Babai, M. Z.; Syntetos, A. A. ABC classification: Service levels and inventory costs. // Production and Operations Management. 19, (2010), pp. 343-352. DOI: 10.1111/j.1937-5956.2009.01098.x

[24] Vahadilla, O. S.; Kumar, S. Analytic hierarchy process: An overview of applications. // European Journal of Operational Research. 169, 1(2006), pp. 1-29. DOl: 10.1016/j.ejor.2004.04.028

[25] Karleuša, B.; Ožanić, N.; Deluka-Tibljaš, A. Improving decision making in defining priorities for implementation of irrigation plans using AHP methodology. // Tehnički vjesnik-Technical Gazette. 21, 3(2014), pp. 673-680.

\section{Authors' addresses}

Orlando Durán A. Ph.D. Professor

Pontificia Universidad Católica de Valparaíso

Avenida Los Carrera 01567, Quilpué, Chile

E-mail: orlando.duran@ucv.cl 